Дочь и зять А. Пушкина: жизнь после разлуки

Аннотация: В статье говорится о том, чем завершается жизненный путь М.Л. Дубельта, приведен ряд фактических свидетельств, позволяющих представить, как воспринималась самими участниками и их близкими драматическая история развода дочери Пушкина Наталии с М.Л. Дубельтом.

Ключевые слова: Наталия фон Меренберг (урожденная Пушкина), Михаил Дубельт, семья Ланских, семья Ольги Павлищевой (урожденой Пушкиной), Лев Павлищев

A.V. Korneev (Moscow, Russia)

\title{
Alexander Pushkin's Daughter and Son-in-law: Life after Separatioin
}

Abstract: The article is devoted to the last days of Mikhael Dubelt's life. Factual evidence presented in the text let us imagine how the participants themselves and their loved ones perceived the dramatic story of the Pushkin's daughter Natalia devorce from Mikhael Dubelt.

Key words: Natalia von Merenberg (nee Pushkina), Mikhail Dubelt, the Lansky family, the family of Olga Pavlishcheva (nee Pushkina), Lev Pavlishchev

В июне 1880 г. в Москве состоялось торжественное открытие памятника А.С. Пушкину, где почетными гостями были дети великого поэта, в том числе и младшая дочь. При встречах они, бесспорно, обсуждали предпринятую ею публикацию писем их отца.

Умирая, вдова Пушкина просила старшую дочь Машу передать младшей самое дорогое - пушкинские письма. Братья согласились с этим, понимая, что, разойдясь с мужем, Таша оказалась в трудном материальном положении. Они были убеждены, что с этим сокровищем та сможет расстаться только в том случае, если все возможности избежать бедности будут исчерпаны и иного способа сохранять прежний образ жизни не останется. Однако Наталия Александровна поступила иначе: она решила продать пушкинские письма, уже став супругой его высочества принца фон Нассау, и никаких материальных затруднений не испытывала. Опубликовав эти письма без ведома братьев и сестры, она поставила их в крайне неловкое положение. 
Мария Александровна, выполняя последнюю волю матери и расставшись с письмами отца, вовсе не ожидала, что так поступит с ними сестра. Поэтому можно понять ее раздражение, когда на слова общей знакомой Е.А. Новосильцевой-Регекампф о жалобах Наталии Александровны на редко получаемые письма она резко ответила: «Скажите ей, что наш отец писал за нас всех».

Младшая дочь поэта несомненно знала пушкинские строки:

Два чувства дивно близки нам,

В них обретает сердце пищу:

Любовь к родному пепелищу,

Любовь к отеческим гробам.

По всей вероятности, ей были чужды эти чувства. Выйдя замуж за немецкого принца и поселившись в Висбадене, она только один раз после этого приезжала в Россию - в 1880 г. на торжества, посвященные открытию памятника Пушкину. По окончании празднества графиня Меренберг вернулась в Висбаден, время от времени посещая с мужем Париж, Лондон и другие европейские столицы и города, однако Петербург и Москва не входили в их число. По всей вероятности, она надеялась прибыть в Россию на юбилей столетия Пушкина, но не получила приглашения. Возможно, сказались осложнившиеся отношения младшей дочери поэта с братьями и сестрой после публикации пушкинских писем в «Вестнике Европы», еще более обострившиеся после их требования передать оригиналы писем в Румянцевский музей. Однако приехать на родину не на празднество и находиться не в центре всеобщего внимания, а просто, без помпезности посетить родные места, где прошли детство и юность, побывать на могилах родителей, приехать в родовое имение Михайловское, встретиться с близкими людьми, - подобная мысль, видимо, не посещала ее.

На торжествах, посвященных открытию памятника Пушкину, Леонтий Дубельт виделся с матерью и подарил ей свою фотографию в морской форме, сделав на обороте надпись на французском языке: «Моей матери, горячо любимой своим сыном. Л. Дубельт 22 мая 1880. Санкт-Петербург». Почти год спустя он напечатал в журнале «Нива» портрет матери в молодости, гравированный Б. Пуцем по рисунку П. Лебедева, с оригинала И.К. Макарова ${ }^{1}$.

Сообщая о появлении дочери поэта вместе с сыном - морским офицером, журналисты отмечали, что тот поразительно похож на своего легендарного деда, каким тот был в молодые годы. Так, в статье «Пушкинский праздник в Москве», напечатанной в журнале «Живописное обозрение», отмечалось: «Между прочим, один из членов этой семьи, молодой моряк, удивительно напоминает чертами лица покойного поэта: те же крупные губы, тот же нос, даже взгляд такой же, как на лучших портретах Пушкина»².

Просматривая послания, написанные дочерью Пушкина в период второго замужества, невольно обращаешь внимание на любопытное обстоятельство.

Еще в телеграмме Наталии Александровны, датированной 1867 г., в которой она сообщала: «..все мои желания исполнены, я замужем», - подписанной «Nathalie, princesse de Nassau», немецкая частица von, указывавшая на дворянское происхождение обладательницы, была заменена французской de, хотя ее вторым мужем стал принц Николаус-Вильгельм фон Нассау. И в дальнейшем, получив титул графини фон Меренберг, на протяжении многих десятилетий подписывая

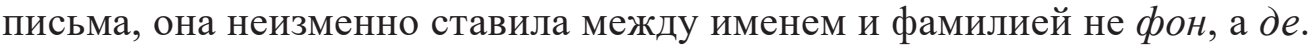

\footnotetext{
${ }^{1}$ См.: Нива. 1881. № 5 .

2 Живописное обозрение. 1880. №25. С. 467.
} 
В РГАЛИ в фонде князей Вяземских хранятся письма Наталии Александровны, писавшиеся в середине 1870-х гг. давнему другу семейства П.А. Вяземскому на французском языке, неизменно подписанные де Меренберг. Известно письмо Наталии Александровны, написанное уже в XX столетии одной из дочерей, подписанное инициалами $H$. де $M$.

И только в надгробной надписи на могиле дочери Пушкина на кладбище Висбадена два раза повторяется немецкое фон:

Grafin Natalie von Merenberg, geboren von Puschkine (1836-1913).

Почти столетие спустя в книге «Дети и внуки Пушкина» Г.А. Галин ${ }^{1}$, говоря о втором замужестве младшей дочери поэта, неизменно именует ее Натальей Александровной фон Меренберг, хотя, думается, von было бы уместнее опустить.

Так поступил И.С. Тургенев в предисловии к публикации пушкинских писем, датированном ноябрем 1877 г.: он, выражая признательность дочери поэта, называл ее графиней Н.А. Меренберг без добавления какой-либо частицы (немецкой или французской) перед фамилией.

Приняв вину в бракоразводном процессе на себя, Михаил Леонтьевич Дубельт в 1863 г. о «по домашним обстоятельствам» был уволен в отставку, продолжавшуюся 23 года. О его жизни в семидесятые годы известно немного.

В марте 1870 г. Дубельт писал Александру II:

Ваше Императорское Величество!

Когда прошлым летом Вы не удостоили меня поступлением вновь на службу, в разговоре Вашем об этом с графом Шуваловым Вы изволили выразиться, что в настоящее горячее время я напрасно не устрою какое-либо выгодное для себя дело или не приму в таком деле участия.

Уже более двух лет я хлопочу постоянно об этом, начинал до десяти превосходных дел, принимал и принимаю участие в предприятиях первоклассных, для России и для правительства весьма выгодных, но к сожалению, все труды мои и усилия разбиваются о ледяное нерасположение ко мне сильных мира сего, весьма отталкивающих меня вследствие Вашего ко мне неудовольствия.

Я бы не осмелился беспокоить Вас, Государь, настоящим письмом, если бы для передачи Вам моей слезной просьбы имел к кому обратиться. Но Вы добры до великодушия, и чем более я был виновен перед Вами, тем конечно охотнее Вы протянете мне руку помощи.

Скажите только министру финансов или графу Бобринскому доброжелательное обо мне слово, и что Ваше Величество не прочь видеть меня участвующим в делах. Тогда мое положение изменится совершенно, и я скоро выйду из несчастия, в котором погряз страшно. Подобною благосклонностию, в выражениях общих, Вы могли бы удостоить даже человека совершенно постороннего. Относительно же меня она возможна, что Отец мой служил Вам как никто, и я имел счастие быть Вашим адъютантом. Бесчестного, клянусь Вам, я никогда не сделал ничего, и с моим здоровьем и с энергией, поверьте, никакого дела не испорчу.

Простите мне, Государь, мою смелость, но право я в отчаянии. Здоровье и состояние брата моего тают как воск, мне существовать положительно нечем, а будущность детей моих устрашает меня. Одно слово, Вашего добрейшего сердца, и Вы увидите, что не пройдет месяца, как я поправлюсь.

Простите и спасите.

Верноподданный и неизменно преданный Михаил Дубельт

6 Марта

1870.

ОР РГБ. Ф. 610. К. 1. Ед. хр. 24. Л. 1.

${ }^{1}$ Галин Георгий Александрович - прямой потомок А.С. Пушкина в четвертом поколении, его праправнук. 
Мы знаем, что Михаил Леонтьевич в скором времени стал правителем дел управления Киево-Брестской железной дороги. Можно было бы предположить, что письмо возымело действие и это назначение произошло благодаря благосклонному отзыву императора и распоряжению министра путей сообщения графа В.А. Бобринского, если бы не одно обстоятельство: Киево-Брестская железная дорога была частной и министру не подчинялась.

В своих воспоминаниях Дубельт пишет, что назначением он был обязан концессионеру дороги Алексею Андреевичу Рябинину, и выражает сожаление, что через год тот передал концессию Е.К. Затлеру, с которым у него отношения не сложились, в результате чего должность правителя дел пришлось оставить.

Михаил Леонтьевич вспоминает также о романтическом путешествии с княгиней Александрой Ивановной Суворовой, с которой находился в свойстве (ее сестра была замужем за его братом) в Восточную Сибирь на золотые прииски ее двоюродного брата Александра Александровича Базилевского.

Назовем некоторые предприятия, в которых участвовал М.Л. Дубельт.

О предложении господина Дубельта о предоставлении ему мощения улиц плитой и по предложению господина С.-Петербургского губернатора об отводе места для производства опыта над чугунной мостовой по Варшавской системе и о рассмотрении проекта господина Дубельта по замощению Петербургских улиц.

ЦГИА СПб. Ф. 787. Оп. 4. 1869-1870 гг. Д. 170.

По ходатайству генерал-майора Дубельта и инженер-механика Кузнецова об учреждении акционерного общества «Кладь» для перевозки кладей, страхования, хранения и выдачи под них ссуд и посредничества в доставлении кладей по железным дорогам и пароходам, $1870-1874$ гг.

РГИА. Ф. 1287 (Хозяйственный департамент Министерства внутренних дел). Оп. 7. 1870 г. Д. 236.

По ходатайству ген.-м. Дубельта, кн. Трубецкого, Долгорукова и др. лиц о разрешении им учредить акционерное общество дешевых продуктов.

ЦГИА СПб. Ф. 792. Оп. 1. 1881 г. Д. 3222.

Как ни удивительно, но два события в жизни Михаила Леонтьевича - причастность к железной дороге и поездка в Сибирь - оказываются взаимосвязаны. Об этом свидетельствует его новое обращение к Александру II, где не только повторяется просьба о принятии на службу, но и предлагается достойный внимания проект - о строительстве Сибирской железной дороги.

После окончания Крымской войны одной из основных причин поражения России в которой стало отсутствие надежных путей сообщения, началось интенсивное сооружение стальных магистралей в страдавшей от бездорожья стране. В 1860-1870 гг. оно получило дальнейшее развитие. М.Л. Дубельт, предпринявший поездку в Сибирь, где он познакомился с предпринимателем и золотопромышленником А.А. Базилевским, проникся идеей строительства железной дороги, необходимой для развития промышленности и оживления этого края, и подал проект о строительстве стальной магистрали, подчеркивая, что оно будет осуществлено без малейших со стороны правительства затрат. Проект интересен еще тем, что написан задолго до строительства Транссибирской магистрали.

Ваше Императорское Величество!

Я имел счастие писать Вам, 27-го прошлого июля, и просить Вас, Государь, простить мне мою виновность перед Вами, и дозволив мое поступление вновь на службу, даровать мне тем самым возможность, моим усердием и преданностию, заслужить хотя отчасти, это драгоценное для меня прощение. При этом, я докладывал Вашему Императорскому Величеству, что под пулями, как и в отдаленном крае, я одинаково буду 
Вашим самым верным слугою, но что я надеюсь принести более существенную пользу на поприще финансовом, так как я последние десять лет моей жизни, исключительно занимался изучением, этой столь важной отрасли Государственного Управления.

Я почти думаю, что письмо мое не достигло своего высокого назначения, ибо никакого распоряжения по нем не последовало. Зная же из опыта моего счастливого прошлого, на сколько Ваше Императорское Величество, добры и благосклонны к каждому, я полагал бы, что если Вам и не благоугодно было снизойти к моей убедительной просьбе, то есть дозволить мое поступление на службу, Вы бы и это решение Ваше, повелели бы передать мне.

Я перенес с покорностию волю Святого Промысла, не допустившего меня принять свою долю участия в гигантской борьбе за честное дело, столь славно окончившейся освобождением Христиан на Востоке, и хотя мое сердце и скорбело от бездействия, в столь торжественные для каждого Русского минуты, я полагал, что по видимому, я еще не достаточно искупил ошибки моего прошлого. Теперь же, когда новые компликации и вызывают к деятельности людей, горячо преданных Престолу и Отечеству, я осмеливаюсь вновь обратиться к милостивому воззрению Вашего Императорского Величества, и убедительно просить Вас, о даровании мне, вновь поступить на службу. В предвидении же возможности, что представленный мною 19-го текущего марта, на благоусмотрение Ваше проект, о неотлагательной постройке Сибирской железной дороги, с ветвию к Индии, и без малейших со стороны Правительства затрат, удостоится Высочайшего одобрения Вашего, - я бы думал, что мое положение на службе, даст мне возможность, с большим еще успехом, следить за осуществлением этого великого патриотического дела, если Вы Государь, дозволите мне о том заботиться.

В ожидании повеления Вашего, и с чувством самой неограниченной преданности, остаюсь,

Вашего Императорского Величества,

30-е марта 1878 г.

верноподданный, Михаил Дубельт

Николаевская ул. 65.

РГИА. Ф. 472. Оп. 37(1305). Д. 7. Л. 45, 45 об., 49.

Заслуживают внимания слова Дубельта о том, что он последние десять лет исключительно занимался изучением финансовых вопросов в надежде, что в дальнейшем познания смогут пригодиться ему на служебном поприще. Это подтверждается высказанным ранее предположением, что «человек выдающегося ума, соединенного с замечательным красноречием» (по мнению вдовы Пушкина Н.Н. Ланской) Дубельт, в случае назначения в 40 лет начальником одной из центральных губерний России, мог бы в дальнейшем стать видным государственным деятелем.

Хотя в 1870-е гг. Россия вела военные действия в Средней Азии, на Кавказе и за Балканами - генерал-майор Дубельт оставался невостребованным.

Много раз безуспешно просивший в письмах Александра II о принятии на службу, Михаил Леонтьевич в 1884 г. обратился к новому императору - Александру III - с той же просьбой. На его прошении император поставил резолюцию: «Можно попробовать дать ему место хоть коменданта, посмотреть, будет ли способен. Уволить всегда есть возможность, если не годится». После двух лет ожидания 6 июня 1886 г. Дубельт был назначен комендантом Александропольской крепости.

Расположенный всего в нескольких верстах от границ Российской империи, Александрополь ${ }^{1}$ был форпостом русских войск в Закавказье. В 1837 г. Николай I

${ }^{1}$ В советское время Ленинабад, ныне Гюмри - второй по величине город Армении. 
заложил рядом с древним поселением Гумры крепость, названную в честь августейшей супруги Александры. Название Александрополь распространилось и на поселение, ставшее городом.

О том, что представлял собой этот город, позволяет понять заметка в первом томе Энциклопедического словаря Брокгауза и Ефрона, вышедшем в свет в тот год, когда Дубельт покинул его: «Александрополь - русский город и крепость в Эриванской губернии, в Закавказье, расположенный на реке Арпчае, и на большой дороге из Эривана в находящий в 45 верстах Карс. Алексанрополь - обширное военное поселение для 10000 человек, имеет 5 церквей и 3 караван-сарая, шелковый промысел и 22670 жителей. (1885). Александропольский уезд Эриванской губернии занимает 37598 кв. м и в уезде населения 111909 жителей»${ }^{1}$.

За девять лет до назначения Дубельта, во время войны за освобождение Болгарии, Александрополь имел большое значение: здесь были сосредоточены главные силы русского корпуса на Кавказе под командованием генерала от кавалерии М.Т. Лорис-Меликова. Однако после взятия Карса и окончания военных действий Александропольская крепость утратила свое значение, должность коменданта стала второстепенной - и теперь командующий войсками Кавказского военного округа князь А.М. Дондуков-Корсаков вел переписку с военным министерством о ее упразднении. Можно представить раздражение князя, когда вопреки его просьбе эта должность не только не была ликвидирована, но на нее был назначен прибывший из Петербурга генерал. Им оказался Дубельт.

Поскольку Дондуков-Корсаков не мог выразить недовольство ни военному министру П.С. Ванновскому, ни тем более императору, то обратил свою досаду на Дубельта. Он очень холодно принял последнего, несмотря на прежнее знакомство и вполне дружеские отношения.

Думается, подобное обращение Дондукова-Корсакова с Дубельтом было вызвано еще одним обстоятельством, о чем последний мог и не догадываться, - ведь тот был зятем Пушкина. Написанная более полувека назад пушкинская эпиграмма «В Академии Наук / Заседает князь Дундук», направленная против его отца, ставшего любимцем и любовником министра народного просвещения С.С. Уварова, благодаря которому отставной полковник и уездный предводитель дворянства сделался попечителем петербургского учебного округа и вице-президентом Академии наук, превратила его фамилию в нарицательное прозвище; слово «дундук», означавшее «бестолковый человек, дурак», вошло даже в «Толковый словарь живого великорусского языка» В.И. Даля.

Казалось, со временем эпиграмма, распространявшаяся в списках и ни разу в России не напечатанная, забылась, но за шесть лет до встречи Дондукова-Корсакова с Дубельтом она неожиданно появилась в печати - в собрании сочинений Пушкина, изданном П.А. Ефремовым. И хотя князь знал, что перед ним человек, ни разу с автором дерзостной эпиграммы не встречавшийся, однако мысль, что это зять Пушкина, пусть даже и бывший, вызывала у него неприязнь и досаду. Эта неприязнь отразилась в написанной два года спустя Дондуковым-Корсаковым аттестации Дубельта: «Здоровья слабого, умственных качеств посредственных, воли слабой, не отвечает своему назначению, по преклонным годам и слабому здоровью не способен к самостоятельной деятельности» ${ }^{2}$. Аттестация была несправедливой и оскорбительной - как характеризовал себя Дубельт в записке,

\footnotetext{
1 Энциклопедический словарь Брокгауза и Ефрона. Т. 1. СПБ., 1890. С. 385.

${ }^{2}$ РГВИА. Ф. 400. Оп. 9. Д. 26439. Л. 12об.-13.
} 
направленной весной 1889 г. в военное министерство: «пользующий замечательным для своих лет здоровьем, пощадившим доныне все его способности» ${ }^{1}$.

К тому же у Дубельта не сложились отношения с начальником городского гарнизона. Следует пояснить, что Александрополь состоял как бы из двух частей города и крепости, отстоявших на расстоянии двух верст одна от другой; при этом в каждой части были свои комендант и гарнизон. Если Дубельт был комендантом крепости и крепостного гарнизона, то комендантом города считался командир расположенной в городе 39-й пехотной дивизии А.В. фон Шак, происходивший из прусских дворян, выпускник Берлинского кадетского корпуса, успевший послужить и в прусской, и в австрийской армиях и только затем перешедший на русскую службу «на ловлю счастья и чинов». И во время смотра Александрополя военным министром П.С. Ванновским фон Шак приписал себе заслуги в нововведениях, сделанных в крепости Дубельтом.

Менее четырех лет был Михаил Дубельт комендантом Александропольской крепости, однако оставил добрую память о себе. В своем письме новому военному министру А.Н. Куропаткину, написанном в 1898 г., Михаил Леонтьевич подчеркивал, что, будучи комендантом крепости, он привел в порядок преданный забвению Холм чести. Так называется военное кладбище с часовней Святого Архистратига Михаила, где были погребены до 240 русских офицеров, погибших в русско-турецкие войны 1855-1856 и 1877-1878 гг. Пришедшее в запустение кладбище стараниями Дубельта было приведено в порядок и благоустроено, высажены до 2500 деревьев и проведена вода ${ }^{2}$. В советское время кладбище было уничтожено, однако в 2010 г. Холм чести восстановлен и освящена часовня. Ныне Холм чести по праву считается достопримечательностью Гюмри - второго по величине города Армении.

Из-за несправедливой аттестации, данной А.М. Дондуковым-Корсаковым и неминуемого упразднения должности коменданта Александропольской крепости Дубельту грозило увольнение в отставку.

Сохранилось письмо Александры Ивановны Дубельт - жены покойного брата Михаила Леонтьевича Николая, - обращенное к некоему Николаю Николаевичу, видимо, сослуживцу покойного мужа, занимавшему видный пост в военной иерархии, от 2 марта 1889 г., в котором она просила принять участие в судьбе beau-frere (деверя) и дать возможность ему не быть уволенным в отставку и дослужиться до полного пенсиона ${ }^{3}$.

Видимо, ходатайство возымело действие. Хотя 27 февраля 1890 г. Дубельт все же был уволен в запас, так как занимаемая им должность Александропольского коменданта ликвидирована, но два последующих года зачтены ему в срок действительной службы. В приказе говорилось: «...в связи с упразднением должности коменданта Александрополя высочайше разрешено Александропольского коменданта генерал-майора Дубельта отчислить от настоящей должности за упразднением таковой с зачислением в запас по армейской кавалерии с оставлением за штатом на два года и с зачетом этого времени в действительную службу» ${ }^{4}$.

Михаил Леонтьевич вспоминал позднее: «По прибытии моем в Петербург, когда я представлялся военному министру (П.С.Ванновскому. - А.К.), то он сказал мне, что я на новое место не должен рассчитывать, так как я слишком стар. "Помилуйте, ваше

\footnotetext{
${ }^{1}$ Там же. Л.7.

${ }^{2}$ См.: РГВИА. Ф. 400. Оп. 9. Д. 26439. Л. 7.

${ }^{3}$ Там же.

${ }^{4}$ Там же. Л. 20.
} 
высокопревосходительство, - возразил я, - мы с вами одних лет, и если вы не слишком стары, чтобы быть хорошим министром, то почему я не могу быть комендантом"»1 ${ }^{\text {. }}$

Однако новую должность Дубельт не получил, и 12 апреля 1897 г. был произведен в генерал-лейтенанты и уволен в отставку с мундиром и пенсией².

«Теперь мне 76 лет отроду, - писал Дубельт 6 мая 1898 г. новому военному министру А.Н. Куропаткину, - и я сознаю, что я действительно стар, чтобы получить какое-либо назначение, но я буду несказанно благодарен Вашему Превосходительству, если Вы исходатайствуйте мне усиление моей пенсии или хотя бы единовременное пособие, так как я действительно нуждаюсь, получая всего на руки 143 руб. в месяц, за удержанием $2 / 5$ из моей пенсии в пользу кредиторов, нажитых мною во время моей продолжительной отставки» ${ }^{3}$.

В декабре 1886 - январе 1887 г. с Наталией Александровной, ставшей во втором замужестве графиней Меренберг, в Висбадене встречался известный историк, редактор-издатель журнала «Русская старина» М.И. Семевский. «Это высокая, видная дама с каштановыми волосами, синими глазами и с громким голосом, - писал он в «Заметках о виденном и слышанном дома и за границей - 1886-1887 гг.». - Она очень приветлива в своем обращении». Во время встреч и бесед Семевский сделал ряд записей по ее воспоминаниям. Однако она совершенно не коснулась семейной жизни, рождения и воспитания детей. Сделанные по ее рассказам записи не завершены; прерванные на середине, они были опубликованы лишь тридцать с лишним лет спустя после смерти Семевского 4

Между тем в редакционном примечании к биографическому очерку о Л.В. Дубельте, напечатанном в ноябрьском номере «Русской старины» за 1888 г., отмечалось: «Еще в 1887 году в Висбадене графиня Наталья Александровна Меренберг (супруга принца Николая Нассауского), дочь великого Пушкина, бывшая в первом браке за сыном Дубельта (брак разведен), с величайшим сочувствием говорила нам о Леонтии Васильевиче» ${ }^{5}$.

Сохраняя память о бывшем свекре, Наталия Александровна не нашла слов сочувствия о первом муже. Вероятно, ее нежелание рассказать о замужестве и семейной жизни и послужило причиной незавершенности записей Семевского.

Однако неприязнь дочери Пушкина к бывшему мужу не отразилась на отношении редактора «Русской старины» к нему: в скором времени М.Л. Дубельт начинает сотрудничать в журнале. В январском номере 1890 г. была напечатана его небольшая статья «Н.О. Сухозанет и император Николай Павлович» - о конфликте с новым военным министром, отрешившим его в 1867 г. от должности, на которую он был назначен покойным императором. Участием в журнале знакомство не ограничивается. 22 июня 1890 г. в альбоме Семевского «Знакомые. Книга автографов» появляется запись Михаила Леонтьевича о его многолетней военной службе. Затем в «Русской старине» публикуется еще ряд написанных Дубельтом мемуарных статей. Помимо этого он рекомендует в журнал нового автора.

\footnotetext{
${ }^{1}$ РГВИА. Ф. 3545. Оп. 3. Д. 495. Ч. 1.

2 Там же.

${ }^{3}$ РГВИА. Ф. 3545. Оп. 3. Д. 495. Ч. 1.

${ }^{4}$ Беседа М.И. Семевского с дочерью Пушкина графиней Н.А. Меренберг // Модзалевский Б.Л., Оксман Ю.Г., Цявловский М.А. Новые материалы о дуэли и смерти Пушкина. Пг., 1924. С. 126-130.

${ }^{5}$ Русская старина. 1888. № 11. С. 497.
} 
В фонде Семевского в Пушкинском доме хранится визитная карточка с надписью: «Михаил Леонтьевич Дубельт просит достойнейшего Михаила Ивановича удостоить своей обычной любезности жены двоюродного брата Л.Н. Павлищева» ${ }^{1}$.

Этот интереснейший человек, приходившийся ближайшим родственником Наталии Александровны, в конфликте супругов Дубельтов принявший сторону ее мужа, бесспорно, заслуживает внимания.

Лев Николаевич Павлищев был сыном старшейㄹ сестры Пушкина Ольги Сергеевны. Она вышла замуж за Николая Ивановича Павлищева - чиновника, историка и журналиста, учившегося в Благородном пансионе при Царскосельском лицее вместе братом Пушкина Львом, близкого знакомого А.С. Пушкина, Е.А. Баратынского, А.А. Дельвига.

В 1829 г. Н.И. Павлищев вместе с М.И. Глинкой издал «Лирический альбом», в который вошли романсы и песни на стихи А.С. Пушкина, В.А. Жуковского, Е.А. Баратынского, а также музыкальные произведения Глинки и самого Павлищева, который интересовался музыкой и искусно играл на гитаре, как семиструнной, так и шестиструнной .

В марте 1831 г. Н.И. Павлищев был переведен в Варшаву, куда полтора года спустя уехала Ольга Сергеевна. В столице Польши 8 октября 1834 г. появился на свет Лев Павлищев ${ }^{3}$. Его отец сообщил о рождении сына Пушкину в письме от 25 октября / 6 ноября. «Левка резов и умен, отличается необыкновенной памятью. Похож очень на своего покойного дядю; больше, нежели собственные дети Александра Сергеевича», - писал Н.И. Павлищев своей матери 26 сентября 1837 г.

После трех лет жизни в Варшаве Ольга Сергеевна вместе с десятимесячным сыном в середине августа 1835 г. отправилась в Петербург. Основной причиной дальнего вояжа стало настоятельное стремление родителей, особенно матери, в то время уже тяжело больной, увидеться с дочерью и внуком. 28 августа мать с сыном прибыли в Петербург и поселились у родителей Ольги Сергеевны на даче в Павловске. Там 30 августа Пушкин впервые увидел Лелю Павлищева - в Павловск поэт с женой приехал с дачи на Черной речке. Как писала Ольга Сергеевна, Александр «очень любит и ласкает своего племянника»

Весьма занятый по службе, помимо этого редактированием газеты и сочинением научных трудов, отец, видимо, мало внимания уделял сыну - воспитанием Левушки занималась его мать.

Три года спустя родилась дочь Надежда, ставшая позднее женой итальянского певца Иосифа Панэ, который по рекомендации ее отца займет должность профессора Варшавской консерватории.

В июне 1849 г. Левушка Павлищев, которому исполнилось четырнадцать лет, окончивший варшавскую губернскую гимназию, был привезен отцом в Петербург для поступления в одно из самых привилегированных учебных заведений тогдашней России - Императорское училище правоведения. Мальчик был радушно принят семейством Ланских-Пушкиных, и прежде всего Наталией Николаевной, и прожил у них два месяца до определения в училище. Лето все семейство, за исключением Петра Петровича Ланского, находившегося в длительной служебной

\footnotetext{
1 Записка написана на визитной карточке Дубельта; к напечатанным имени, отчеству и фамилии приписаны несколько слов. Ниже напечатан адрес Дубельта: Сергиевская ул, № 81, кв. 11. На обороте текст на французском языке: Le General Doubelt. Sergievskaya, 81, log. 11 (ИРЛИ. Ф. 274. Оп. 1. № 147). 2 В Интернете сообщается, что мать Л.Н. Павлищева Ольга Сергеевна была младшей дочерью Пушкина. На самом деле она была старше поэта на полтора года.

3 Там же ошибочно указано, что Павлищев родился в Петербурге.
} 
поездке, проводило в Петербурге на Каменном Острове, где на земле графа Строганова был разбит великолепный сад и построено здание искусственных минеральных вод, в зале которого проходили концерты известного в то время оркестра Иоганна Гунгля, выступали фокусники и клоуны.

В письмах Наталии Николаевны мужу, написанных в эти месяцы, неоднократно упоминается впечатлительный одаренный мальчик, который напоминал ей первого мужа. «Горячая голова, великолепное сердце, кровь Пушкина», - писала она о нем 3 июля.

«Никто не наслаждался этим спектаклем с таким восторгом, как Азя*1 и Леон Павлищев; этот последний хлопал в ладоши и разражался смехом на все забавные проделки полишинеля. Веселость его была так заразительна, что мы больше веселились, глядя на него, чем на спектакль. Это настоящая ртуть - этот мальчик, он ни минуты не может спокойно сидеть на месте, но при всей своей живости необыкновенно послушен и сто раз придет попросить прощения, если ему было сделано замечание... Леон развлекает нас своим пением, музыкой, своим остроумием. Он беспрестанно ссорится и мирится со своей кузиной Машей, но это не мешает им быть лучшими друзьями на свете» (29 июня).

«Сейчас все они (дети) собрались около фортепиано и поют; Леон Павлищев - Гунгль этого оркестра» (1 июля). «Леон Павлищев играл на фортепиано...» (10 августа).

«..Я попрощалась с Леоном, бедный мальчик заливался слезами. Я обещала ему присылать за ним по праздникам и что он может быть быть спокоен: я его не забуду. Мы расстались очень нежно» (16 августа).

«Забыла тебе сказать, что Леон Павлищев приехал вчера из своего училища провести с нами два дня. Бедный мальчик в совершенном отчаянии, и достаточно произнести слово правоведение, как он разражается потоком слез. Его уже бранил директор за то, что он вечно плачет. - "Что вы хотите, - сказал мне Леон, - я ничего не могу поделать, достаточно мне вспомнить о парке Строгановых и о том, как мне хорошо живется у вас, как сердце мое разрывается". Это ребенок меня трогает, в нем столько чувствительности, что можно простить ему небольшие недостатки... Я не смогла удержаться и не сделать замечание Саше, что, расставаясь с нами, он не испытывал и четвертой доли того горя, что его двоюродный брат» (22 августа).

«Саша и Леон приехали провести с нами воскресенье... Леон, кажется, привык немного, но еще печален» (28 августа).

Не приходится сомневаться, что и в дальнейшем Наталия Николаевна не забывала про свое обещание. И три с половиной года спустя, когда ее дочь, она же кузина Леона Павлищева Таша Пушкина, вышла замуж, в числе приглашенных на свадьбу, бесспорно, был и восемнадцатилетний юноша, похожий на великого поэта.

Лев Павлищев проучился три года в Училище правоведения. В мае 1852 г. он вместо перехода на старший (университетский) курс оставил это замкнутое аристократическое учебное заведение и поступил на юридический факультет более демократичного Петербургского университета, который окончил три года спустя со степенью кандидата прав.

Как мы сумели убедиться, знакомясь с рассыпанными в письмах Наталии Николаевны замечаниями о Леоне Павлищеве, написанными при его поступлении в Училище Правоведения, они свидетельствовали о тонкости, чувствительности,

${ }_{1}^{1}$ Азя (Александра Петровна Ланская, в замужестве Арапова) - дочь Наталии Николаевны от второго брака; к моменту написания письма ей было три года. Примечательно, что Павлищев, которому вскоре исполнится 15, с таким же непосредственным восторгом, как и трехлетняя девочка, воспринимает выступление клоуна. 
эмоциональности и детском восприятии действительности племянника Пушкина. Таким же тонким, чутким, восприимчивым, детски непосредственным племянник Пушкина остался и пятнадцать лет спустя, уже став кандидатом прав, - об этом говорят страницы его дневника (ИРЛИ).

Однако следует отметить еще одно душевное качество Павлищева - его необычайную честность. Если просмотреть его послужной список, невольно удивляет число мест службы, которое переменил он за короткое время, После окончания университета он служил в Красносельской удельной конторе; с 6 декабря 1856 г. в Департаменте уделов, с 11 февраля 1857 г. - в Петербургской таможне, с 4 апреля 1857 г. - в Департаменте внешней торговли, с 25 октября 1859 г. - в канцелярии Военного министерства, с 15 сентября 1864 г. - в Главном интендантском управлении. Столь частые перемены мест службы можно объяснить одним - честность Павлищева не могли понять его сослуживцы, стремившиеся нагреть руки на выгодных должностях: они считали его крайне непрактичным и глупым человеком, отказывающимся от денег, которые, казалось, сами плыли ему в руки. Тогда, видимо, и возникло прозвище «идиот», закрепившееся за ним.

В 1860-е гг. племяннику великого поэта суждено было познакомиться с другим великим писателем. И не только познакомиться, но и стать одним из прототипов главного героя созданного этим писателем романа.

Действие романа Ф.М. Достоевского «Идиот» начинается в поезде Петербурго-Варшавской железной дороги. В вагоне завязывается разговор между двумя попутчиками, которым предстоит стать соперниками в любви к одной женщине. В начале разговора возникает фамилия Павлищев - она принадлежит покровителю главного героя, отправившего его лечиться в Швейцарию; ее произносит главный герой, еще не успев назвать себя: князь Лев Николаевич Мышкин.

Не случайно появляется в романе фамилия Павлищев. Не случайно главный герой романа - полный тезка реально существовавшего Льва Николаевича Павлищева.

Как установила литературовед Г.Л. Боград, Достоевский был знаком с Павлищевым. Они познакомились в Павловске, где оба проводили летние месяцы. Бесспорно, внимание писателя прежде всего привлекло внешнее сходство Павлищева с Пушкиным. Затем при более близком знакомстве писатель смог отметить и оценить душевные качества этого человека: предельную искренность, тонкость, эмоциональность, чувствительность, детскую восприимчивость действительности.

Все эти душевные качества уже известны нам: о них писала Наталия Николаевна в письмах мужу летом 1849 г., когда Леон Павлищев жил у них, готовясь поступать в Училище Правоведения.

Петербург и Варшава - два города, с которыми связан Павлищев: в Варшаве он появился на свет и жил почти пятнадцать лет, затем в Петербурге учился и служил, после продолжил службу в Варшаве и, наконец, вернулся в Петербург, где прожил почти сорок лет и умер в 1915 г.

Мать Льва Павлищева Ольга Сергеевна, расставшись с мужем, переехала в Петербург и в течение нескольких лет проводила летние месяцы на даче в пригороде столицы - Павловске, где когда-то тоже жили на даче ее родители. Поездом Петербурго-Варшавской железной дороги в Варшаву, где служил его отец, ездил Лев Николаевич, который несколько лет спустя сам переведется туда.

Начавшееся в вагоне поезда действие романа в последующих главах первой части происходит в Петербурге. Во второй части события сначала также развертываются в столице, но в скором времени перемещаются в Павловск, где и продолжаются вплоть до последней главы, чтобы завершиться в Петербурге. 
Мысль о том, что Льва Павлищева носил в детстве на руках Пушкин, вероятно, не без юмора повторялась им, отмечавшим, что только этим и ограничилось его общение с великим поэтом. Эта фраза своеобразно отразилась в романе: ею генерал Иволгин почти всегда начинал разговор с молодыми людьми при знакомстве с ними.

Во второй половине жизни Павлищев обратился к творчеству.

«В течение очень долгого времени писал я для себя воспоминания о своем детстве, юности и дальнейших затем событиях моей жизни, - говорится в предисловии к «Семейной хронике». - Воспоминания эти, касающиеся меня лично, не могут большею частию представлять большого интереса для читающей публики. Вот почему я и не вижу надобности предавать гласности все мои воспоминания... Но среди этих воспоминаний, скажу без самоуверенности, находятся страницы, которые мне было бы просто грешно не сообщить читателям».

«Семейная хроника» печаталась в 1889 г. в «Историческом вестнике», затем вышла отдельной книгой - «Воспоминания о Пушкине. Из семейной хроники»

Правда, для пушкинистов мемуары Павлищева, основанные на рассказах матери и семейной переписке, не представляют значительного интереса. Однако для широкого читателя их значение велико: в них отразилась пушкинская эпоха, атмосфера того времени, образ мыслей, круг интересов образованного общества. И, разумеется, сам Пушкин, его родные и друзья.

Не случайно эти воспоминания неоднократно переиздавались в последние годы, в том числе под броским заглавием, придуманным издателями-коммерсантами, - «Мой дядя - Пушкин»; существует также их электронная версия.

Таким был человек, которого Михаил Дубельт рекомендовал редактору «Русской старины» Семевскому. Об их взаимоотношениях можно судить по фрагменту письма, написанного Л.Н. Павлищевым сестре:

17 мая [1873?]

Тебе очень кланяется... отгадай кто? Михаил Леонтьевич Дубельт. Встретились мы с ним на улице, и я забрел к нему на чашку чая и на бутылку превосходного пива. Среди дружеской беседы время прошло незаметно. На поверку выходит - не он, а жена его кругом виновата. Сделав с ним в последнее время такую штуку - уже будучи замужем за Ник..., так ему насолила по службе, что твой Фукс'1.

Михаил Леонтьевич занимается теперь частной службой и несмотря на свои 50 лет, нисколько не переменился. Надо было видеть, как он мне обрадовался, надо было слышать, с каким участием о тебе расспрашивал, о твоем пребывании в Варшаве, о твоем муже, детях. В заключение выпили за твое здоровье, и велел тысячу раз поцеловать твои ручки. Все, что об нем говорили Ланские и tutti quanti ${ }^{2}$ - чистая чепуха. Живет он прекрасно, и такой же ком иль $\phi o^{3}$, как и был. Не верь людям - они злы и рады очернить всякого, кто им не по вкусу4

${ }^{1}$ Фукс Виктор Яковлевич (1829-1891) - член Главного управления по делам печати при Министерства внутренних дел; в конце 1860-х гг. участвовал в разработке цензурного устава Царства Польского и в своем докладе в 1870 г. дал отрицательную оценку газеты «Варшавский дневник», издаваемой Н.И. Павлищевым, в результате чего издание было прекращено и Павлищев лишился должности его директора. По настоянию Н.А. Меренберг министр внутренних дел А.Е. Тимашев негативно охарактеризовал в докладе императору М.Л. Дубельта, в результате чего Александр II не согласился на его назначение помощником генерал-губернатора Восточной Сибири. Об этом пишет в своих воспоминаниях Михаил Леонтьевич (РГВИА).

${ }^{2}$ Всякие другие (ит.).

${ }^{3}$ Ком иль фо (comme il faut - фр.) - соответствующий понятиям светского приличия; о костюме человека, особенностях поведения, манерах, умении вести беседу.

${ }^{4}$ РГАЛИ. Ф. 2281. Оп. 1. Ед. хр. 676. Л. 12 и об. Выражаю признательность хранителю музейных предметов Государственного музея А.С. Пушкина Наталии Алексеевне Александровой за публикации, посвященные Л.Н. Павлищеву и его дружбе с М.Л. Дубельтом. 
Сохранилось несколько писем, написанных самим Михаилом Леонтьевичем Л.Н. Павлищеву в последние годы и даже дни жизни, в которых он называет адресата «мой дорогой друг и брат», «достойнейший и добрейший» и «душевно благодарит» его.

По тону писем можно судить, что знакомство Дубельта и Павлищева было близким и они часто общались. И хотя мы не располагаем сведениями о том, когда это знакомство началось, тем не менее можно с уверенностью предполагать, что произошло оно в феврале 1853 г. на свадьбе Михаила Леонтьевича с Наталией Александровной Пушкиной. По всей вероятности, оно продолжалось до отъезда Дубельтов в Елизаветград и возобновилось с их возвращением в Петербург. Также живя в столице, Лев Павлищев, конечно, слышал о раздорах в семье Дубельтов, приведших к бракоразводному процессу, - не только как близкий родственник Ланских-Пушкиных, но и как правовед; возможно, с ним даже советовались как со знатоком юриспруденции. Павлищев не мог не знать как о начале процесса, возникшего по инициативе его кузины Наталии Александровны, так и о его окончании, а также о последовавшем затем высочайшем разрешении проживать ей отдельно от мужа, идущем вразрез с законодательством.

В мае 1899 г., когда Россия отмечала столетие со дня рождения Пушкина, были организованы юбилейные выставки - в Академии наук в Петербурге и в Историческом музее в Москве. В свет вышли альбомы, посвященные выставкам, в которых в числе других изображений были помещены и портреты Леонтия Васильевича Дубельта. Неизвестно, побывал ли Михаил Леонтьевич на одной из этих выставок. Однако можно не сомневаться, что благодаря Павлищеву, принимавшему деятельное участие в организации выставок, он видел эти альбомы, в том числе и портреты отца.

За две недели до кончины Михаил Леонтьевич писал Павлищеву:

Дорогой друг и брат милейший Лев Николаевич!

Кроме моего постоянного желания видеться с тобой, мне необходимо переговорить с тобой по одному обстоятельству, приехать же к тебе не имею возможности, потому что не встаю с постели третью неделю вследствие сильной простуды. Будь такой Ангел, по окончании твоей службы в Контроле заезжай на минутку ко мне. А добрейшая Ольга Петровна вероятно простит меня, что в этот день ты явишься домой на полчаса позже. Крепко тебя обнимаю, Ольге Петровне целую ручки. Душевно тебе преданный

20е марта 1900 г.

М. Дубельт.

ИРЛИ РАН. Ф. 221. Ед. хр. 30967. Л. 6-7.

Михаил Леонтьевич ушел из жизни в последний год XIX столетия.

«6-го Апреля умер М.Л. Дубельт. Завтра его похороны, - писала Павлищеву невестка Михаила Леонтьевича Александра Ивановна, вдова его брата Николая. - Он был болен две недели, умер, как святой, заснул. Хоронят его в Невском монастыре». Дубельт был погребен на Никольском кладбище Александро-Невской лавры.

Ушел из жизни Михаил Леонтьевич несостоятельным должником. После его кончины остался неоплаченный вексель на 2200 рублей. Назначенная опека пришла к выводу о невозможности выплатить эту сумму - из-за отсутствия у покойного имущества. 
Нельзя сказать, что кончина Дубельта не осталась совсем незамеченной: в печати появились два некролога. Однако что они собой представляли!

В газете «Северный курьер» была напечатана заметка в несколько строк, сиротливо затерявшаяся на большеформатной полосе между хроникой происшествий и перечнем приехавших в Петербург:

«НЕКРОЛОГ. На днях скончался отставной генерал-лейтенант Михаил Леонтьевич

Дубельт, сын знаменитого шефа жандармов Л.В. Дубельта. Покойный родился в 1818 г., службу начал в кавалергардском полку, участвовал в крымской кампании (причем был тяжело ранен); был флигель-адъютантом Императора Александра II. В 1881 г. он вышел в отставку. Перу покойного принадлежит несколько статей и заметок в «Рус. Старине», где он преимущественно полемизировал с разными мемуаристами, неблагосклонно относившимися к памяти его отца ${ }^{1}$.

Грустное впечатление производит эта заметка. Несмотря на краткость она полна неточностей. Отец Михаила Леонтьевича был не шефом жандармов, а управляющим Третьим отделением. Сам он родился не в 1818 г., а четырьмя годами позднее. Дубельт не участвовал в Крымской войне и ранен был в сражениях с горцами на Кавказе. Вовсе не в 1881, а в 1863 г. он был вынужден выйти в отставку, которая продолжалась 23 года. В 1886 г. Дубельт был назначен комендантом Александропольской крепости и пробыл в этой должности четыре года. В 1890 г. он был уволен в запас, а семь лет спустя - вторично в отставку.

Немногим отличается и некролог в «Историческом вестнике». Восемь строк журнального текста почти полностью повторяют предыдущий. К тому же в научном журнале не только повторяются ошибки газетного некролога, но покойному М.Л. дважды приписаны инициалы его отца - Л.В.

Совершенно несправедливо сказано, что в «Русской старине» Михаил Леонтьевич «преимущественно полемизировал с разными мемуаристами, неблагосклонно относившимися к памяти его отца». Ему было о чем рассказать! Об этом убедительно говорят даже те немногие публикации, которые появились. Вот что говорилось в них:

- конфликт с военным министром, сместившим его с престижной должности, на которую он был назначен покойным императором;

- участие в реформе по отмене крепостного права и гордость за умение убедительно разъяснить крестьянам ее пользу, не прибегая ни к телесным наказаниям, ни тем более к стрельбе и убийству;

- наконец, близкое знакомство с Александром II, вначале наследником престола цесаревичем, затем императором, продолжавшееся более десяти лет.

Однако многое так и осталось несказанным.

Проведя более двух лет в Петербурге в доме отца, Михаил Леонтьевич, бесспорно, не раз перечитывал бережно хранившиеся письма матери, которые она писала мужу, - в них часто встречалось и его имя.

Выпущенный после окончания Пажеского корпуса в 1840 г. в блистательный Кавалергардский полк, Михаил Дубельт прослужил в нем почти десять лет. Однако в феврале 1849 г. он круто меняет судьбу: переводится на Кавказ в скромный Апшеронский пехотный полк.

Этот решительный шаг одобрил не отец - в прошлом сам боевой офицер, участник «грозы двенадцатого года» и заграничных походов, а мать Михаила.

\footnotetext{
${ }^{1}$ Северный курьер. 1900. № 159.
} 
Приведем отрывки из ее письма от 28 февраля 1849 г.: «...жизнь его в Петербурге слишком ничтожна и бесполезна, чтобы не наскучить ему... Труды, заботы, хлопоты, ночи без сна, дни без пищи, огорчения - все ничего не значит, как скоро он знает и уверен, что все-таки он приносит пользу отечеству и ближним. А какую же пользу может принести Мишинька в Петербурге, даже во фронте? Между тем такая бесполезная жизнь раздражает его... даже страшно подумать, что при таких обстоятельствах, если б не было никакой перемены, он мог бы сойти с ума».

Прибыв на Кавказ, Дубельт в скором времени принял участие в осаде укрепленного горского аула Чох и отличился в сражении 23 августа. Однако в реляции его имени не оказалось, хотя командир Апшеронского полка князь Г.Д. Орбелиани в разговоре со старшим братом Михаила Николаем высоко отзывался о младшем. Вероятно, отсутствие имени майора Дубельта в донесении произошло оттого, что на время осады Чоха он был прикомандирован к другому полку - князя Варшавского (Орловскому) и в его составе участвовал в боевых действиях. Позднее в числе других участников сражения Дубельт был награжден золотой саблей с надписью «За храбрость».

Два года спустя Дубельт вновь участвует в военных действиях на Кавказе. Предстояло взять штурмом горное плато Турчидаг, занятое горцами под началом самого Шамиля. Батальон Дубельта был направлен по крутому скалистому скату Турчидага на скопище горцев, открывших «убийственную» стрельбу. В начале боя Дубельт был ранен в ногу навылет, но, несмотря на сильную боль, продолжал вести батальон. Карабкаясь с одного уступа на другой, апшеронцы поднялись на обрывистый край Турчидага. Тогда горцы, не решаясь вступить в рукопашный бой, поспешно отступили. За этот подвиг майор Дубельт досрочно был произведен в подполковники. В реляции князь Аргутинский-Долгоруков отметил Дубельта в числе офицеров, которые «наиболее обратили на себя внимание распорядительностью и отважностью своею».

Как была рада Анна Николаевна Дубельт, узнав о том, что ее сын Миша женится. Как полюбила будущую невестку, так ни разу не повидав ее, - и в своем последнем, предсмертном письме писала, что желала бы видеть ее фрейлиной больше, чем сына флигель-адъютантом. Как просила мужа не откладывать свадьбу, если не сумеет из-за болезни вовремя приехать.

Как радовалась свадьбе мать невесты: «Я желать лучшего зятя не могла», признавалась Наталия Николаевна Вяземскому.

Как стремился Михаил Дубельт убедить жену сохранить семью - хотя бы ради детей. Как предлагал супруге варианты дальнейшей жизни:

1) «Будь великодушна, прости меня, испытай еще раз, последний раз. Даю тебе честное слово, что при первом твоем требовании я возвращу тебе полную и совершенную свободу»;

2) «Будем жить врознь. [...] Ты меня никогда не увидишь, но будь уверена, что самая пламенная молитва моя к Богу та, чтобы ты со временем меня простила, чтобы ты возвратилась ко мне, хотя бы через 20 лет, хотя бы к смертному одру моему».

3) «Развод, но с одним условием: я всю вину беру на себя и чтоб ты осталась невинною. [...] Клянусь тебе душою покойного отца моего, что с первого до последнего слова все искренно и все будет в точности исполнено».

Однако самолюбивая дочь Пушкина решает добиться расторжения брака самостоятельно: «Быть может, я достигну той же цели и без твоего содействия, но сохраняя право тебя ненавидеть». Наталия Александровна не согласилась повре- 
менить с началом бракоразводного процесса до тех пор, пока Михаил Леонтьевич не будет утвержден в должности губернатора, хотя и понимала, что процесс помешает назначению мужа. И действительно, Дубельт получил уведомление от графа Адлерберга, сообщавшего, что по воле императора он не должен рассчитывать на получение должности.

Более полутора лет длился бракоразводный процесс, в результате которого Наталии Александровне было отказано в расторжении брака. Однако она, пользуясь покровительством сановников, в виде исключения получила свидетельство на право жить отдельно от мужа. Высочайшая резолюция, перечеркивавшая решение Духовной консистории сохранить семью, потрясла Дубельта и заставила обратиться к императору с поразительным по резкости письмом: «Повелением Вашим, как гражданин и отец, я оскорблен и уничтожен окончательно... Убежденный в Правосудии Вашем, я смело и громко скажу Вам, что Вас на мой счет обманули и я наказан Вами вполне безвинно».

Это письмо Александр II не простил Дубельту.

18 ноября 1865 г. Дубельт вновь писал императору - теперь из Парижа:

Уехав навсегда из дорогой мне России, откуда я изгнан несправедливостию и самоуправством людей сильных, - я обращаюсь еще раз к Вам, Государь, дабы Вы знали истину... Пока я был в моем родном отечестве, я не осмелился бы столь решительно передать Вам правду, не из опасения Вас, честнейшего и благороднейшего из всех, но из опасения князей Суворова и Долгорукова, которые сумели бы из мести еще больше уничтожить меня, чем уже уничтожили, из желания угодить Наталье Александровне. Повторяю, Государь, что я прошу у Вас в четвертый раз не милости или снисхождения, но только правды, то есть суда и следствия законного - вещи, которых не лишены даже преступники и арестанты.

Дубельт не скрывает, что у него было намерение написать о своих бедах в редакцию «Колокола».

Летом 1866 г. Наталия Александровна похитила младшую дочь Анну; в сентябре имение Дубельта за долги было продано с аукциона.

1 июля 1867 г. в Лондоне дочь Пушкина обвенчалась с принцем Николаусом Нассауским и сделалась двоемужницей, поскольку не развелась с Дубельтом. Между тем к суду привлекалась не она (за двоебрачие), а он - за измену жене, бывшей почти год замужем за другим.

В декабре 1867 г. Дубельт был уличен в прелюбодеянии, которое было явно инсценировано. В мае 1868 г. Святейший синод признал расторжение брака «с предоставлением г-же Дубельт вступать в новый брак и с осуждением генерал-майора Дубельта на всегдашнее безбрачие».

Задумывалась ли Наталия Александровна, выйдя замуж за принца Нассауского, о том, кто пожертвовал счастьем ради того, чтобы была счастлива она? Как вспоминался он ей? Ответ на эти вопросы дает «Петербургский роман», написанный ею полтора столетия назад на немецком языке, но увидевший свет в наши дни.

Уже в XXI в., в семейном архиве правнучки Наталии Александровны Меренберг графини Клотильды фон Ринтелен отыскалась старинная рукопись, написанная на немецком языке. В 1950 г. она была получена ее отцом, графом Александром фон Меренберг, из Аргентины от его тетки Алы де Элия, также урожденной фон Меренберг, после кончины последней.

Старая рукопись, написанная готическим шрифтом, который и в тогдашней Германии разбирали не очень многие, никого не заинтересовала, и долгие десяти- 
летия она пылилась непрочитанной в шкафу. Только в 2002 г. графиня Клотильда решила ознакомиться с ее содержанием. Каково же было ее изумление, когда она обнаружила, что перед нею роман из петербургской жизни середины XIX в., описывающий историю первого замужества дочери Пушкина Наталии Александровны. А три года спустя, в 2005 г., роман уже вышел в русском переводе под интригующим заглавием на обложке - «Роман дочери Пушкина, написанный ею самой».

Это произведение отнюдь не воспоминания, а действительно роман, в котором имеет право присутствовать (и действительно присутствует!) вымысел. Правда, все персонажи носят другие имена и фамилии, однако в главной героине Вере Громовой, видимо, подразумевается сама Наталия Александровна. Следует обладать немалым воображением, чтобы угадать в молодом графе Владимире Островском, влюбленном в героиню, Николая Орлова, а в другом офицере, Борисе Беклешове, ставшем ее мужем, - Михаила Дубельта. Только упоминание, что отец Николая шеф жандармов, а отец Михаила - служащий под его началом генерал, помогают осознать это. В результате интриг двух отцов Николай отсылается с дипломатическим поручением в Париж, а Борис женится на Вере и назначается губернатором в Ярославль, где он изменяет жене, заведя роман с некоей Любочкой (компаньонкой Веры - персонаж явно вымышленный), а затем и с одной из губернских дам.

Роман завершается тем, что Борис Беклешов, лишенный императорским указом чинов и дворянства и разжалованный в рядовые с высылкой на Кавказ, кончает жизнь самоубийством, а Николай год спустя соединяется брачными узами с Верой.

Как видим, все это страшно далеко от истины.

О том, что Наталия Пушкина беззаботно веселилась на великосветских балах, не думая о том, что некогда любимый ею Николай Орлов страдает от жестоких ран, даже не упоминается. Не говорится и о том, что она завела роман с иноземным принцем и, покинув Россию, уехала к нему, бросив трех детей на попечение отчима. Умалчивается и то, что Михаил Дубельт не изменял жене, которую очень любил.

Переводчик романа на русский язык, он же автор послесловия к нему В.М. Фридкин, не удовлетворившись оценкой, данной в произведении Борису Беклешову, не жалеет черных красок, характеризуя его прототип - Михаила Дубельта: «Картежник и мот, необузданный скандалист, кутила и хам, каким он предстает в романе, таким он был и в жизни, по воспоминаниях современников. Мотаясь с женой по провинциальным гарнизонам... он проиграл в карты все приданое жены... а в следующем году [смог] перебраться на службу в Министерство иностранных дел».

Сказанное тут целиком неверно.

Прежде всего позволительно спросить: на какие воспоминания и на каких современников ссылается В.М. Фридкин, называя Дубельта «скандалистом, кутилой и хамом»? В своих записках А.П. Арапова кратко и сдержанно отзывается о Дубельте и упоминает только о «необузданном нраве, о страстном темпераменте игрока». То же самое говорит она и о Пушкине. Лаконичную, но сугубо положительную характеристику дает в письме сестре А.О. Россет, узнав о женитьбе своего доброго приятеля: «Радуюсь за Наталью Николаевну и за Ташу. Дубельт очень хороший малый, хотя и был, что называется, разбитной; у него, как мне казалось, хорошая натура» ${ }^{2}$. Другие воспоминания нам неизвестны.

\footnotetext{
${ }^{1}$ Русский архив. 1896. №3. С. 380.
} 
Вновь обратимся к характеристике Дубельта, данной В.М. Фридкиным.

Вряд ли можно назвать «мотанием по провинциальным гарнизонам» ответственные командировки по городам России по поручению военного министра. Затем Дубельт приказом Николая I был назначен начальником штаба кавалерийского корпуса, в состав которого входило 30 полков и 23 конных батареи, составлявшие пять кавалерийских и одну конно-артиллерийскую дивизию.

Вынужденный покинуть эту престижную (генеральскую!) должность, хотя он сам был полковником, в результате интриг, зять Пушкина ненадолго перешел на службу в Министерство внутренних дел, но отнюдь не иностранных, где продолжил после лечения карьеру Николай Орлов. Фридкин говорит, что Дубельт проиграл приданое жены, но не упоминает, что эти деньги вернулись к ней сполна благодаря написанному им заемному письму. Не говорится и о том, что он сумел успокоить взволновавшихся крестьян 14 имений, не наказав при этом ни единого человека. Расставшись с женой, Дубельт - в результате интриг он лишился состояния, положения, семьи; предоставил жене свободу и возможность выйти замуж за любимого человека ценой собственной обреченности на вечное безбрачие - прожил весьма небогатым человеком долгую жизнь и умер, не оставив никакого имущества.

История, как известно, не знает сослагательного наклонения. И все же попытаемся представить: если бы юная Таша Пушкина вышла бы замуж за Николая Орлова, в которого была влюблена, как бы сложилась их совместная жизнь.

Во время Крымской войны полковник Николай Орлов при осаде Силистрии в мае 1854 г. жестоко пострадал - получил девять тяжелых ран и лишился глаза, после чего долго лечился. Его жене, если бы в то время он был женат, пришлось бы отказаться от выездов в свет, уделяя все внимание израненному супругу.

«Что муж в сраженьях изувечен» - эти слова Татьяны Лариной, ставшей княгиней, невольно приходят на память.

Сумела бы выдержать столь тяжкие душевные испытания Таша Пушкина, став княгиней Орловой, которой было тогда всего восемнадцать? Мы знаем, что она помнила того, кто был первой ее любовью.

Об этом мы узнаем из воспоминаний С.М. Загоскина, сына знаменитого исторического романиста, напечатанных в 1900 г. в «Историческом вестнике». Переносясь мысленно почти на полвека назад, он упоминает о знакомстве в мае 1857 г. на великосветском балу с младшей дочерью Пушкина: «Я был представлен ей приятельницею ее княжной Суворовой, и к моему великому удовольствию, дочь Пушкина подарила меня несколькими приветливыми словами... До своего первого замужества она была сильно влюблена в князя Николая Алексеевича Орлова, страстно ее любившего и желавшего на ней жениться, но отец его, шеф жандармов князь Алексей Федорович не допустил этого брака, считая дочь Пушкина неподходящей невестой для своего сына (Слышано мной от самой Натальи Александровны)» ${ }^{1}$.

Видимо, Наталия Александровна не страдала излишней скромностью, если отважилась поведать о своей первой любви почти незнакомому человеку. К тому же она отчего-то не вспомнила, что тот, кого она некогда любила, ныне страдает от жестоких ран.

Скромной и тихой жизни, о которой мечтала ставшая княгиней Татьяна Ларина, Наталия Александровна предпочла блеск и пышность балов. Можем ли мы упрекать ее за это?

\footnotetext{
${ }^{1}$ Загоскин С.М. Воспоминания // Исторический вестник. 1900. № 6. С. 51-50.
} 
Думается, многие представительницы прекрасного пола на ее месте поступили бы подобным образом. Восхищенная блеском аристократических балов молодая женщина упивалась вниманием многочисленных поклонников и беззаботно веселилась, предпочитая не думать о тяжкой судьбе, постигшей любимого некогда ею человека.

Невольно вспоминаются поэтические строки графини Евдокии Ростопчиной (ее стихотворения вышли вторым изданием незадолго до встречи С.М. Загоскина с дочерью Пушкина):

А я, я женщина во всем значеньи слова,

Всем женским склонностям покорна я вполне.

Я только женщина... гордиться тем готова.

Я бал люблю...отдайте балы мне.

Завершая работу о судьбе зятя Пушкина, следует высказать некоторые суждения, предвидя возможные возражения.

Михаила Дубельта обвиняли в ревности. Однако эта ревность была отнюдь не беспочвенной. Многие мужья на его месте не менее мучительно сомневались бы в верности любимой жены, благосклонно принимавшей восторженное внимание поклонников. Достаточно вспомнить, как ревновал Натали Пушкин, за которой увивался Дантес.

Автор этих строк далек от мысли ставить знак равенства между Пушкиным и Дубельтом, равно как тот же знак между их супругами.

Известны воспоминания Е.А. Новосильцевой-Регекампф, где говорится о жестоком обращении Дубельта с женой: «У нее на теле остались следы его шпор, когда он спьяну, в ярости топтал ее ногами».

Обвинение более чем серьезное, но можно ли ему верить? Воспоминания писались семь десятилетий спустя описываемых событий, в 1927 г., и вряд ли можно считать их абсолютно достоверными.

Между тем известен официальный документ - медицинское свидетельство, написанное в начале бракоразводного процесса, 21 августа 1862 г., в имении Брогиан (ныне Бродзяны), где гостила в то время Наталия Александровна: ее тетка Александра Николаевна была замужем за владельцем имения бароном Г.Ф. фон Фризенгофом. В заключении, подписанном врачом, лечившим семейство Фризенгофов, говорится о заболевании «супруги Императорско-Российского Генерала Натальи Дуббельт», выраженном «хронической и упорной охриплостью», т. е. болезнью горла, - ни о чем другом в свидетельстве не упоминается ${ }^{1}$. Такой весомый аргумент, как документ, зафиксировавший следы избиения, Наталия Александровна, добивавшаяся развода с мужем, разумеется, представила бы в Консисторию.

Тем не менее Дубельт не только прощал жене неверность, но признавал жестокое обращение с ней, просил прошения, брал вину на себя в распаде семьи и умолял вернуться - хотя бы ради детей. Об этом свидетельствует его письмо, написанное 19 июня 1862 г., обращенное к ней, - оно приводилось в первой части нашей работы. Напомним некоторые строки:

«Начну с того, что искренно прошу у тебя прощения в том, что довел тебя до этой крайности, ибо, по всей справедливости, я виновный»;

«Самая пламенная молитва моя к Богу та, чтобы ты со временем меня простила, чтобы ты возвратилась ко мне, хотя бы через 20 лет, хотя бы к смертному одру моему»;

${ }^{1}$ ЦГИА СПб. Архив Санкт-Петербургской духовной консистории 1862 г. Д. 117. Оп. 1. Л. 6 (перевод); ранее не публиковалось. Избегая объяснения с мужем, Наталия Александровна писала о невозможности приезда в Россию, мотивируя это заболеванием, что подтверждала документально. 
«Развод, но с одним формальным условием, что я всю вину беру на себя и чтоб ты осталась невинною. - Это совершенно справедливо, так как вина вся на моей стороне, и довел тебя до настоящего положения я».

Отблеск славы Пушкина падает на его детей - они предстают в отраженном свете его ореола. С юных лет мы привыкли к этому. В наших глазах они непогрешимы. Между тем у каждого из них были своя жизнь, свои достоинства и недостатки.

Не следует любовь или неприязнь, испытываемые к знаменитым людям, однозначно переносить на их детей. В советское время было принято в конфликте семейства Дубельт - Пушкина обвинять мужа - сына управляющего Третьим отделением (начальника политической полиции Российской империи), в то время как его жена, дочь поэта, оставалось непогрешимой.

Подобные утверждения не опровергнуты до сих пор. Ради доказательства вымышленных сведений людей вводят в заблуждение, утаивают или искажают факты.

Настала пора истины - и читатели, не имеющие возможность изучить хранящиеся в архивах документы, должны знать историческую правду.

Судьба Михаила Леонтьевича Дубельта, имевшего несчастье полюбить дочь Пушкина, безусловно, достойна внимания и заслуживает достоверного освещения.

Сведения об авторе:

Алексей Вениаминович Корнеев, историк русской литературы XIX века член Союза писателей РФ
Aleksey V. Korneev,

The Historian of Russian Literature of the $19^{\text {th }} \mathrm{c}$.

Member of the Union of Writers

of the Russian Federation

korneev-kav@mail.ru 